\title{
Table of decisions
}

\section{NATIONAL}

\section{Australia}

Dietrich v. R [1992] 109 ALR 385 ................................................................ 51

Re Greenham and Minister for Capital Territory [1979] 2 ALD 137 ............... 81

Kioa v. West [1985] HCA 81; (1985) 159 CLR 550 ..................................... 46

Minister for Immigration and Citizenship v. Li [2013] HCA 18; (2013) 249

CLR 332 ................................................................................... 55

Re Visa Cancellation Applicant and Minister for Immigration and Citizenship

[2011] AATA 690

\section{Canada}

Abdelrazik v. Canada (Minister of Foreign Affairs) [2010] 1 F.C.R. 267

(4 June 2009) $180-81$

Knight v. Indian Head School Division No. 191990 CANLII 138, [1990] 1 S.C.R. 653 46

\section{Gaza}

YY v. UNRWA 17 August 1957 (Gaza) 35

\section{Italy}

Allied Headquarters in Southern Europe [HAFSE] v. Capocci Belmonte Corte di Cassazione, 5 June 1976

\section{Singapore}

Tang Kin Hwa v. Traditional Chinese Medicine Practitioners Board [2005]

SGHC 153, (2005) 4 S.L.R.(R.) [Singapore Law Reports (Reissue)] 46

\section{Switzerland}

Nada v. State Secretariat for Economic Affairs, Bundesgericht [BGer] [Federal Court] 14 November 2007, 133 Enscheidungen des Schweizerschen Bundesgrichts [BGE] 11450 180,195 


\section{UK}

Arab Monetary Fund v. Hashim and Others, House of Lords, 21 February 1991, 85 ILR1

Associated Provincial Picture Houses Ltd. v. Wednesbury Corporation [1948]

$1 \mathrm{~KB} 223$

Council of Civil Service Unions v. Minister For The Civil Service

(The GCHQ Case) [1985] AC 374, (1985) ICR 14

HM Treasury v. Ahmed [2010] UKSC 2920102 WLR 378

Locabail (UK) Ltd. v. Bayfield Properties Ltd. [1999] EWCA Civ 3004, (2000) Q.B. 451

R v. Commission of Police in the Metropolis, ex parte Blackburn [1968]

2 QB 118

\section{USA}

Steinberg v. International Criminal Police Organization, US Court of Appeals

DC Cir., 23 October 1981

\section{INTERNATIONAL}

\section{European Court of Human Rights}

Al Jedda v. The United Kingdom Application no. 27021/08 (ECtHR, 7 July 2011)

Behrami and Behrami v. France and Seramati v. France, Germany and Norway Application No 71412/01 and Application No, 78166/01, (ECtHR 2 May 2007)

Kadi and Al Barakat International Foundation v. Council Joined Cases C-402/05 and C-415/05, [2008] ECR 1-6351, Judgment, September 2, 2008 $180,185,194$

Kadi v. Council and Commission Case No. T-315/01 [2005] ECR II-3649, Judgment, September 21, 2005 181,185

Yassin Abdullah Kadi v. European Commission Case No. T-85/09 [2011] 1 CMLR 24, 30 September 2010 $182,185,195$

Nada v. Switzerland Application no. 10593/08 (ECtHR, 12 September 2012)

Ryabykh v. Russia Application no. 52854/99 [2003] (ECtHR, 24 July 2003) European Court of Justice ......................................................................... 68

Segi v. Council, Case No C-355/04 [2007] ECR I-8361, Judgment, 11 October 2007 


\section{International Court of Justice}

Applicability of Article VI, Section 22, of the Convention on the Privileges and Immunities of the United Nations (Mazilu Case) (Advisory Opinion)

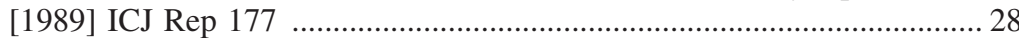

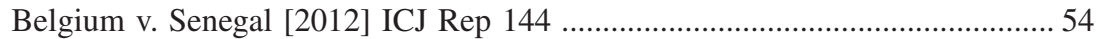

Certain Expenses of the United Nations (Article 17, Article 2, of the Charter) (Advisory Opinion) [1962] ICJ Rep 151 .............................................. 28

Conditions of Admission of a State to Membership in the UN (Advisory Opinion) [1948] ICJ Rep 57

Effect of Awards of Compensation Made by the United Nations Administrative

Tribunal (Advisory Opinion) [1954] ICJ Rep, 47 70

Interpretation of the Agreement of March 251951 between the WHO and

Egypt (Advisory Opinion) [1980] ICJ Rep 73

Legal Consequences for States of the Continued Presence of South Africa in

Namibia (South West Africa) notwithstanding Security Council Resolution

276 (1970) (Advisory Opinion) [1971] ICJ Rep 16

Legality of the Threat or Use of Nuclear Weapons (Advisory Opinion) [1996]

ICJ Rep 226

Military and Paramilitary Activities in and against Nicaragua (Nicaragua v.

United States of America) [1986] ICJ Rep 14 29,57

Reparations for the Injuries Suffered in the Service of the United Nations (Advisory Opinion) [1949] ICJ Rep 174 $28-9$

\section{UN Appeals Tribunal}

Andronov v. Secretary-General of the United Nations UNAT/2004/1157

(30 January 2004)

Applicant v. Secretary-General of the United Nations UNAT/2012/209

(16 March 2012)

Assale v. Secretary-General of the United Nations UNAT/2015534

(2 July 2015)

Igbinedion v. Secretary-General of the United Nations UNAT/2014/410

(2 April 2014)

Koda v. Secretary-General of the United Nations UNAT/2011/130

(8 July 2011)

Lutta v. Secretary-General of the United Nations UNAT/2011/117

(11 March 2011)

Molari v. the Secretary-General of the United Nations UNAT/2011/164

(21 October 2011)

Nguyen-Kropp \& Postica v. Secretary-General for the United Nations

UNAT/2016/273 (30 June 2016)

Nwuke v. Secretary-General of the United Nations UNAT/2010/ 099

(28 December 2010)

Tabari v. Commissioner General of the UN Relief and Works Agency for

Palestine Refugees, UNAT/2010/30 (30 March 2010)

Zhouk v. Secretary-General UNAT/2012/224 (29 June 2012) 


\section{UN Dispute Tribunal}

Abboud v. Secretary-General of the United Nations, UNDT/2011/001

(6 January 2010)

Ademagic et al v. Secretary-General of the United Nations, UNDT/2012/131

(29 August 2012)

Atana v. Secretary-General of the United Nations UNDT/2012/068

(19 April 2013)

Cabrera v. Secretary-General of the United Nations UNDT/2011/081

(6 May 2011)

Comerford-Verzuu v. Secretary-General of the United Nations UNDT/2011/

005 (10 January 2011)

di Giacomo v. Secretary-General of the United Nations (UNDT/2011/168)

(29 June 2012)

Flaetgen v. Secretary-General of the United Nations (UNDT/2014102)

(21 July 2014)

Hocking, Javis, McIntyre v. Secretary-General of the United Nations.

UNDT/2009/077 of 20 November 2009

Kashala v. Secretary-General of the United Nations UNDT/2014/023

(28 February 2014)

Kiwanuka v. the Secretary-General of the United Nations UNAT Judgment No. 941 (1999)

Kunanayakam v. Secretary-General of the United Nations

UNDT/GVA/2010/027 (10 January 2011)

M'bra v. Secretary-General of the United Nations UNDT/2010/185

(18 October 2010)

Nguyen-Kropp \& Postica v. Secretary-General for the United Nations UNDT/2013/176 (20 December 2013)

Nouinou v. Secretary-General for the United Nations UNDT/NY/2016/054 (26 October 2016)

Planas v. Secretary-General of the United Nations UNDT/2009/086 (10 December 2009)

Powell v. Secretary-General of the United Nations UNDT/2012/039 (28 March 28, 2013)

Survo v. Secretary-General of the United Nations UNDT/2015/069 (30 July 2015)

Syed v. Secretary-General of the United Nations UNDT/2009/093 (22 December 2009)

Tiwathia v. Secretary-General of the United Nations UNDT/2015/021 (17 March 2015)

Worsley (Order No. 079 (GVA/2010), UNDT/2011/024 ((27 January 2011)

\section{UN Human Rights Committee}

A v. Australia UN Doc CCPR/C/59/D/560/1993 (30 April 1997) .................... 62 Lederbauer v. Austria Communication No 1454/2006 (11 September 2007) ... 63

Perterer v. Austria Communication No 560/1993 (30 April 1997) 62 
Sayadi and Vinck v. Belgium UN Doc CCPR/C94/D1472/2006 (22 October 2008) $179,191,195$

YL v. Canada Communication No 112/1981 (8 April 1996)

\section{WTO Appeals Body}

United States-Import Prohibition of Certain Shrimp and Shrimp Products, WTO Doc WT/DS58/AB/R, 98-3899 (Oct. 12, 1998)

\section{World Bank}

World Bank Administrative Tribunal Reports [1981], Decision No. 1 32 